\title{
Fiscal Correction Effect to Commercial Financial Statements for Corporate Income Tax
}

\author{
Diana Sari and Florentina Anjar Anggraeni
}

\begin{abstract}
Fiscal reconciliation is an adjustment of commercial financial statements that have been prepared by the taxpayer with the provisions of the tax legislation. In the reconciliation, there emerged differences between commercial profit and taxable income in the form of fiscal correction, which can be categorized into two groups: permanent differences and temporary differences. This study aims to determine the effect of permanent differences and temporary differences on corporate income tax either partially or simultaneously. The research was conducted in 6 Telecommunications Industry Company listed in Indonesia Stock Exchange, with a financial statements sampling period of 2009 until 2011. The research methodology used in this study is a descriptive analysis method, with a survey-study approach. Statistical testing using multiple linear regression analysis. The results showed, partially permanent differences have significant influence on corporate income tax, but temporary differences do not have significant influence on corporate income tax and simultaneously, permanent differences and temporary differences are altogether have significant effect on corporate income tax.
\end{abstract}

Index Terms-Fiscal correction, permanent differences, temporary differences, corporate income tax.

\section{INTRODUCTION}

Tax is a contribution charged to the taxpayer on income earned and have forced power. Taxation in general serves as revenue and setting. Taxes as a source of state revenue is used to finance the government's interests such as routine interests and development interests. While functioning as a setting meant taxation is used to regulate the social and economic life of society. Therefore, the government passed laws and regulations on taxation. In the implementation of tax collection as a mandatory contribution, there is a difference of interests between the taxpayer and the Government. For taxpayers, tax collections are often considered to be a "scourge" especially for companies with large income. This is due to the collection of tax by the government will reduce the earnings it receives.

Meanwhile, the government, wants higher taxes on companies that become taxpayers. The interests difference caused taxpayers to likely want to reduce the number of tax payments, both legally and illegally, especially if there are opportunities that can be exploited [1].

In Indonesia, the accounting standards conducted by taxpayers, especially corporate taxpayers, is the Statements of Financial Accounting Standards (SFAS or PSAK), where generated profits were included in the income statement and is called as the accounting profit, while the basis for calculating

Manuscript received October 1, 2013; revised December 5, 2013.

The authors are with the Widyatama University, Bandung, Indonesia (e-mail: diana_sari570@yahoo.com, florentina.anjar@widyatama.ac.id). the tax payable is the accounting profits that has been adjusted to taxation laws and generated taxable income (fiscal profit). Government compile laws and regulations of taxation to increase state income not specifically to measure performance. So it can be ascertained that the calculation results between accounting profits and taxable profit will be different [2]. The basis of tax for company is income before taxation that were contained in the financial statements of income. Financial statements play an important role in the company. Financial statements such as the Statement of Financial Position, Income Statement, as well as Cash Flow Statement reflects the company's financial health. Besides, the financial statements also play an important role in determining the amount of tax to be covered by the company. Companies generally compile two types of financial statements for tax and accounting purposes. The financial statements for accounting purposes is known as commercial financial statements which refers to the Financial Accounting Standards, while the financial statements for tax purposes is known as fiscal financial statements which refers to the tax regulations.

The preparation of fiscal income statement carried based on commercial income statements through fiscal correction. Therefore, the fiscal financial statements are different from the commercial financial statements. The differences between these two financial statements lie in the the recognition of income and expenses. In addition, the fiscal financial statements contained corrections to temporary differences and permanent differences, each of which can be both positive and negative. Positive temporary differences occur when the recognition of expenses for accounting is slower than the recognition of expense for taxes, whereas a negative temporary differences occur when the recognition of expense for the tax is slower than the recognition of accounting expense. While positive permanent differences occur when there is accounting profits is not recognized by the tax regulations, whereas negative permanent differences occurs when there is burden of accounting profit that is not recognized by the tax regulations. The differences between commercial financial statements and tax financial statements has led to differences in the large calculation of the taxable income of a company that is determined by fiscal income statement [1].

A study conducted on companies financial statements from 1988 to 1999 to measure the amount of difference in income that is calculated by accounting rules and income calculated by taxation rules, which lead to the conclusion that there are significant differences between accounting profits with fiscal profits caused by certain factors [3]. There are several factors that cause the differences between accounting profit with fiscal profit, the first one is the differences between the rules of accounting and the rules of taxation regarding the income 
and expense recognition time. These time difference causes the number of revenue recognized in accounting profits to be different with the one recognized in fiscal profit for a particular period, but after a certain period of time these differences will be discharged/ nil. The second factor is differences that arise between accounting profit and fiscal profit when revenues and expenses are recognized by one of the system but not by the other system (also called permanent differences).

The author chose Telecommunications Industry companies as the research object because the development of telecommunications industry is increasing rapidly, where many consumers demand for new means of telecommunication operators have sprung up with various types and features supporting their product as superior. Looking at the development of the telecommunications world provide opportunities for investors to invest in this telecommunications field. The development of Telecommunications Industry in Indonesia is now vastly potential, because of the great level of demand and consumer tastes that are now generally of high level mobility, as well as of the affordable means of telecommunication in all circles made consumers can enjoy more than one provider of telecommunications service and products.

\section{LITERATUR REVIEW}

\section{A. Commercial Financial Statements}

Commercial financial statements are financial statements which are compiled based on International Financial Reporting Standards (IFRSs) [4]. Commercial financial statement is the result of a combination of recorded facts with accounting principles using accruals basic concepts, proper matching of cost and revenue, conservative, and materiality [5]. The accrual basic concept meant that commercial financial statements prepared in accordance with the facts recorded. Proper matching of cost and revenue shows exact combination between expenses and revenues. Conservative is the concept of prudence to estimate the losses that have been able to be recognized by providing an allowance or reservation at the end of the year. While the concept of materiality is used by the auditor to state wether it is fair or not fair in assessing the commercial financial statements.

Commercial financial statements can be divided into two elements namely income and expenses. The elements in the commercial financial statements can be explained as follows [4]:

1) Income. Income is defined as the addition of assets or decreases of liabilities that result in an increase in equity not resulting from the contribution of capital investment. Earnings in a company include revenue and profits. Revenue is part of the income. Income is defined as income derived from the activity of the company includes sales, service income, interest, dividends, royalties and rent.

2) Cost. Cost reduction in income or an increase in accounts payable. In terms of utilization, costs can be divided into two: the cost of capital and income. Capital costs are expenses that benefit more than one accounting period and recorded as assets. While cost is an expense that provides income benefits for one accounting period and are recorded as an expense. Expense in the financial statements also includes the commercial unrealized losses or damages arising from the effect of foreign currency exchange difference.

\section{B. Fiscal Financial Statement}

Fiscal financial statements are financial statements prepared under taxation laws used for the benefit of the tax calculation [4]. Fiscal financial statements as a result of the adjustment to pre-tax revenue from the income statement to calculate the income tax [6]. Correction in the income statement is referred to as the fiscal correction conducted so that the accounting profit adjusted for taxation laws to produce fiscal profit.

Based on that opinion, fiscal financial statements can be interpreted as a financial statements prepared based on taxation laws by first making corrections to income before taxes from commercial income statement to obtain fiscal profit which then used to determine or calculate the income tax.

\section{Fiscal Correction}

Fiscal correction is the adjustment of commercial financial statements for the preparation of fiscal financial statements [4]. Fiscal correction is done because of the differences in the recognition of income and cost between commercial and fiscal financial statements giving rise to differences in calculating the amount of taxable income.

Cause of the difference between pre-tax income and taxable income and potentially also lead to differences between income tax expense and income tax payable, can be categorized into the following five groups [7]:

\section{1) Permanent differences}

This difference occurs because under the provisions of the tax laws, there are some that are not taxable income, while commercial income is recognized as revenue. Vice versa, there are some costs in accordance with the taxation laws and regulations, including fiscal costs that are not deductible, whereas the commercial cost calculated as the cost.

\section{2) Temporary differences}

This difference occurs because under the provisions of the tax legislation is income or deductible expenses in the accounting periods proceeding or subsequent accounting period of the current accounting period. Meanwhile, a commercially recognized it as income or expense in the period in question.

\section{3) Loss compensation (operating loss carry forward)}

Commercially, there is no recognition of loss compensation, but under the provisions of the tax law, if there is a loss may be carried forward for five years in a row the following year after the loss occurs.

\section{4) Investment tax credit}

When a company is buying or constructing a particular asset, then a certain percentage of the cost of the asset can be credited (deducted) from the income tax payable on the acquisition of the asset. Investment Tax Credit is not causing the difference between pre-tax income and taxable income, but there will be differences between tax expense and income tax payable. 


\section{5) Tax allocation intraperiode (intraperiod tax} allowance)

For the purposes of commercial financial statements, income tax amount distributed to:

- Income continuing operations

- As a result of the operation does not continue

- Extraordinary things

- Cumulative effect of change in accounting principle in the statement of financial

- Adjustments to previous period.

Therefore, companies have to make adjustments to the financial statements at the end of period which is the so-called reconciliation. Reconciliation contains explanations or differences occurred between commercial financial statements and fiscal financial statements.

Fulfilling the purposes of taxation, fiscal correction is divided into a positive fiscal correction and negative fiscal correction, whereas for the purposes of the application of SFAS 46, divided into permanent differences and temporary differences (timing difference).

Definition of the difference permanent and temporary differences is [7]:

1) Permanent difference is the difference between accounting profit and taxable income caused by tax regulations and will not cause any accounting problems and did not have any impact on future tax liabilities. This difference consists of income that has been deducted by final income tax, income which is not subjected to tax, expense included in the non-deductible expense (article 9 paragraph 1 of the Income Tax Act) and is not included in the deductible expense (Article 6 paragraph 1 of the Income Tax Act).

2) Temporary difference is the difference in accounting profit and taxable profits caused by the tax provisions and give effect to in the future within a certain period so that the impact on accounting profit and taxable profit will ultimately be the same.

Taxable income derived from the amount of profit before taxes adjusted / reconciled by doing: (1) positive correction, if the difference causes increased revenues and reduced costs according to fiscal; and (2) negative correction, if the difference caused reduced revenues according to fiscal and costs are increasing according to fiscal.

\section{Income Tax}

Definition of income tax in accordance with Article 1 of Law No. 36 of 2008, the income tax is an income tax that is imposed on the tax subject on income which is received or accrued during the tax year.

\section{E. Corporate Taxpayers}

Every taxpayer, both individual taxpayers and corporate taxpayers, are required to carry their tax obligations. Definition of corporate taxpayers under article 1, paragraph 3 of the the General Provisions and Tax Procedures Law (CTP Law) is a set of people and/or capital which is a either unit that conduct business or did not conduct business that includes a limited company, limited company partnership , other forms of company, state-owned or owned by the region with names and form of any kind, firm, joint venture, coop, pension funds, alliance, associations, foundations, mass organizations, socio-political organizations, or other organization, institution or other forms of institution including collective investment contract and permanent establishment.

\section{RESEARCH METHOD}

The object under study is the fiscal correction and corporate income tax. This study was conducted to examine the effect of fiscal correction which are permanent difference and temporary difference on corporate income tax of Telecommunications Industry companies listed in Indonesia Stock Exchange. The variables used by the writer in this study is quantitative. The unit of analysis in this study is companies. Companies studied are Telecommunications Industry company listed in Indonesia Stock Exchange that have gone public.

In this study, the population taken are all Telecommunications Industry companies that have gone public and listed on the Indonesia Stock Exchange during the period from 2009 to 2011 .

To determine the sample to be used in this study, the authors take the purposive sampling technique. Criteria used in the selection of the sample is as follows:

1) The Telecommunications Industry listed in the Indonesia Stock Exchange (IDX) of the year 2009-2011.

2) Released Annual Financial Report 2009-2011 data and the complete data is available.

3) The company balance is profit, because if the company balance is loss then income tax expense do not exist.

\section{FINDING AND DISSCUSION}

Quantitative data obtained by the researcher will be presented as variables involved in the study based on indicators and measurement scales that have previously been defined. The data were collected on 9 Telecommunications Industry companies listed in Indonesia Stock Exchange (IDX), but the data taken only from 6 companies with a span of over 3 years from 2009 to 2011.

\begin{tabular}{lll} 
& & TABLE I: SAMPLE OF STUDY \\
\hline \hline No & Code & Telecommunications Companies \\
\hline 1 & TRIO & PT Trikomsel Oke Tbk. \\
2 & TLKM & PT Telekomunikasi Indonesia Tbk. \\
3 & INVS & PT Inovisi Infracom Tbk \\
4 & CENT & PT Centrin Online Tbk. \\
5 & EXCL & PT XL Axiata Tbk. \\
6 & TELE & PT Tiphone Mobile Indonesia Tbk. \\
\hline \hline
\end{tabular}

TABLE II: MULTIPLE REGRESSION ANALYSIS AND T TEST

\begin{tabular}{|c|c|c|c|c|c|}
\hline \multirow[t]{2}{*}{ Model } & \multicolumn{2}{|c|}{$\begin{array}{c}\text { Unstandardized } \\
\text { Coefficients }\end{array}$} & \multirow{2}{*}{$\begin{array}{c}\begin{array}{c}\text { Standardized } \\
\text { Coefficients }\end{array} \\
\text { Beta }\end{array}$} & \multirow[t]{2}{*}{$t$} & \multirow[t]{2}{*}{ Sig. } \\
\hline & $B$ & Std. Error & & & \\
\hline (Constant) & $1.433 \mathrm{E} 11$ & $8.882 \mathrm{E} 10$ & & 1.613 & 0.127 \\
\hline Permanent_Differences & -0.080 & 0.033 & -0.560 & -2.441 & 0.028 \\
\hline Temporary_Differences & -0.031 & 0.110 & -0.064 & -.281 & 0.783 \\
\hline
\end{tabular}

The regression coefficients and partial and multiple 
correlation, obtained form of multiple regression equation as follows: $Y=143.300 .000 .000-0,080 X_{1}-0,031 X_{2}$ Interpretation is as follows:

1) $a=143.3$ billion is the intercept value, which means that the regression line cut the $Y$ axis at a point 143.3 billion and also is dependent on the estimated value at the time the value of $X_{1}$ and $X_{2}$ equal to zero.

2) $b_{1}=-0.080$ is the coefficient of linear regression direction, which means that any increase in permanent differences $\left(X_{1}\right)$ by 1 unit will cause a decrease in corporate income tax $(Y)$ of 0.080 units, assuming temporary differences $\left(X_{2}\right)$ constant.

3) $b_{2}=-0.031$ is the coefficient of linear regression direction, which means that any increase in temporary differences $\left(X_{2}\right)$ by 1 unit will cause a decrease in corporate income $\operatorname{tax}(Y)$ amounted to 0,031 units, with the assumption of permanent differences $\left(X_{1}\right)$ constant.

The level of the relationship between each independent variable can be determined by using partial correlation coefficients, while the magnitude of the effect of each independent variable on the dependent variable, assuming no changes in other independent variable that are defined by using partial determination coefficient. Partial determination coefficient obtained by squaring the partial correlation coefficients from each variable.

TABLE III: PARTIAL CORRELATION COEFFICIENT

\begin{tabular}{llll}
\hline \hline \multirow{2}{*}{ Model } & \multicolumn{3}{c}{ Correlations } \\
\cline { 2 - 4 } & Zero-order & Partial & Part \\
\hline (Constant) & & & -0.509 \\
\hline Permanent_Differences & -0.586 & -0.533 & -0.059 \\
\hline Temporary_Differences & -0.296 & -0.072 & \\
\hline \hline
\end{tabular}

a. Dependent Variable: Corporate_Income_Tax

Permanent differences $\left(X_{1}\right)$ shows that the magnitude of the partial correlation of $-0,533$. The relationship between permanent differences with corporate income tax has a strong cohesion. Temporary differences $\left(X_{2}\right)$ indicate that the magnitude of the partial correlation of $-0,072$. The relationship between temporary differences with corporate income tax has a very weak cohesion.

TABLE IV: DETERMINATION COEFFICIENT

\begin{tabular}{ccccc}
\hline \hline Model & $R$ & $R$ Square & $\begin{array}{c}\text { Adjusted } R \\
\text { Square }\end{array}$ & $\begin{array}{c}\text { Std. Error of the } \\
\text { Estimate }\end{array}$ \\
\hline 1 & $0.589 \mathrm{a}$ & 0.347 & 0.260 & $3.324 \mathrm{E} 11$ \\
\hline \hline
\end{tabular}

a. Predictors: (Constant), Temporary_Differences, Permanent_Differences

b. Dependent Variable: Corporate_Income_Tax

In a study on the relationship between the free variables with the bound variable it is often desired to know just how the power of the free variables simultaneously explains changes in bound variables. Determination coefficient $\left(R^{2}\right)$ using the R square of $(0,589)^{2}=0,347$ gives the sense that the amount of corporate income tax that can be explained by the amount of permanent differences and temporary differences amounted to $34,7 \%$ and the remainder is $65,3 \%$ is explained by other factors that were not studied and is not included in this model.
The hypothesis testing stage is intended to determine whether the regression obtained by the study have any meaning when used to make conclusions about the relationships from a number of variables that is being studied. Partial test is conducted to determine the effect of one of the independent variable with the dependent variable assuming other variables constant. Test results are as follows:

1) The effect that occurs between the permanent differences variable and corporate income tax variable is significant.

2) The effects that occur between the temporary differences variables and corporate income tax variable is not significant.

3) The effect of permanent differences and temporary differences (simultaneously) against the corporate income tax variables is significant.

Permanent differences are the differences between accounting profit and taxable income caused by tax regulations and will not cause any accounting problems and do not give effect to the tax problems in the future. Permanent differences include the following expenses which are included in non-deductible expense (Article 9, paragraph (1) income tax laws) and are not included in the deductible expense (Article 6, paragraph (1) income tax laws).

Relationship between permanent differences $\left(X_{1}\right)$ with corporate income tax are identified by the beta coefficient of $-0,080$. The negative coefficient can be interpreted that between permanent difference and corporate income tax there are opposite relationship of 0,080 . If the permanent differences increased by 1 unit, then corporate income tax would decrease by 0,080 units.

This negative correlation indicates that the higher the permanent difference, the lower the corporate income tax. A negative relationship between permanent differences with corporate income tax is due to the expense as accounting profit expenses that are not recognized by the fiscal provisions [4]. Then the negative fiscal correction is carried which resulted in reduced corporate income tax.

At the 5\% significance level, partially there are significant effect between the permanent difference variables to corporate income tax variable, assuming temporary differences variables are considered constant. It supports the research conducted which states that there is a negative relationship and significant effect between permanent difference and taxable income [8].

Based on the results the partial determination coefficient also showed that the permanent difference of $53,3 \%$ on corporate income tax. This supports the statement that the permanent difference effect significantly on corporate income tax.

Temporary differences are the differences between accounting profit and taxable income caused by the tax provisions and give effect in the future within a certain period so that the effect on the accounting profit and taxable income ends up being the same. These temporary differences include depreciation of fixed assets. Relationship between temporary differences $\left(X_{2}\right)$ with corporate income tax are identified by the beta coefficient amounted $-0,031$. The negative coefficient can be interpreted that between temporary differences with corporate income tax an opposing relationship exists amounted 0,031. If the temporary differences increased by 1 unit, then the corporate income tax 
will be decreased by 0,031 units.

A negative relationship between temporary differences with corporate income tax occur if expense recognition for tax purposes is quicker than the expense recognition for accounting or income recognition for tax purposes is slower than revenue recognition for accounting purposes [9]. For the time difference between the income recognition and expenses, negative fiscal correction is carried that resulted in reduced corporate income tax. The difference between recognition time and cost according to tax regulations with accounting that could resulted in a negative fiscal correction is [10]:

1) Depreciation that taxpayers calculated is lower than the amount of depreciation according to tax accounting calculation.

2) Amortization that taxpayers calculated is lower than the amount of amortization according to tax accounting calculations.

3) Deferred recognition of costs.

At the 5\% significance level, partially there are no significant influence between the temporary differences variables to corporate income tax variable, assuming the permanent difference variables are considered constant. Based on the results of the partial determination coefficient also showed that temporary differences only gives $7.2 \%$ influence on corporate income tax. These results support the statement that temporary differences are not significantly influence corporate income tax.

Hypothesis testing that has been applied previously by using the F test; to test the effect simultaneously indicates the independent variables (permanent differences and temporary differences) have a significant influence on corporate income $\operatorname{tax}$.

A study conducted on the financial statements of companies from medium to large scale from 1988 to 1999 to measure the income differences that is calculated by accounting rules and income that is calculated by the tax rules lead to the conclusion that fiscal correction has significant influence on taxable income [3].

Based on this study, it is suggested that management can manage the onset of permanent differences and temporary differences so that differences arising between commercial profit with fiscal net income can be minimized. Properly managing tax liabilities can result in tax savings and at the same time avoiding companies from the imposition of tax penalties both administrative sanctions and taxation crime sanctions.

For the Government, in order to provide convenience and simplicity in calculating income tax payable, suggested the following matters [11]:

1) In order to minimize or avoid the onset of temporary differences resulting from methods, income and costs.

2) In order for tax provisions socialization to be implemented on an ongoing basis with the involvement of the whole society such as educational institutions, entrepreneurs and civil servants as well as the military/police for the ease of obtaining tax information and services will encourage taxpayer compliance in implementing the obligations and rights in the field of taxation.
3) To encourage the creation of good corporate governance, expenses in the form of donations directly related to the business continuity of companies to be considered as an expense (deductible expense). If donations can be imposed, then expenses must be supported with complete evidence so it can be accounted for. During this time, the expense should not be treated as costs, so this may encourage management to impose it with the name of another account on fiscal income statement.

\section{CONCLUSION}

Based on the findings in the previous chapters as well as discussion that is accompanied by supporting theories, it can be concluded as follows:

1) Permanent differences variables partially have a negative relationship on corporate income tax, meaning that the higher the number of permanent differences, the lower corporate income tax. This is evidenced by beta coefficient that is negative in value, which is $-0,080$. Permanent differences partially have significant influence on corporate income tax.

2) Temporary differences variables partially have a negative relationship on corporate income tax, meaning that the higher the number of temporary differences, the lower corporate income tax. This is evidenced by beta coefficient that is negative in value, which is $-0,031$. Temporary differences partially did not have significant influence on corporate tax.

3) Permanent differences variables and temporary differences variables simultaneously have a significant influence on corporate tax.

4) Temporary differences do not have a significant effect on corporate income tax because it is basically the difference will be recovered over time.

5) Corporate is expected to apply tax management to reduce fiscal correction differences both derived from the permanent differences and temporary differences so that there is no big difference between commercial income with taxable income. Corporate should be more careful in making financial statements with respect to the fiscal rules adopted in the Act in order to minimize the differences that led to a correction.

6) For researchers interested in conducting further research on this topic can be explore any permanent differences that influence corporate income tax

\section{REFERENCES}

[1] A. L. Situmorang, "Reconciliation of financial statements analysis of financial statements fiscal commercial with in calculation of income tax payable (VAT) at PT. Alam Jaya Wirasentosa," Research Journal of Sekolah Tinggi Ilmu Ekonomi IBBI, North Sumatra, 2006

[2] H. Frank and W. Kross. (2005). Book Versus Taxable Income. [Online]. Available: http://papers.ssrn.com

[3] G. B. Manzon and G. A. Plesko. (2002). The relation between financial and tax reporting measures of income. Journal Tax Law Review. [Online]. 55. Available: http://papers.ssrn.com

[4] S. Erly, Tax Planning, Jakarta: Salemba Empat, 2011, pp. 81-87.

[5] D. H. Gustian, Personal Income Tax, Jakarta: Salemba Empat, 2003, pp. 16.

[6] Purba, Marisi P dan Andreas, Accounting for Income Taxes Under IAS No. 12 and SFAS No. 4, Yogyakarta: Graha Ilmu, 2005, pp. 7.

[7] Z. Mohammad, Management of Taxation, Jakarta: Salemba Empat, 2007, pp. 212-213. 
[8] S. Yosef, Influence Commercial Income and Fiscal Correction against Taxable Income in Textile Industry in Indonesia Open for the Year 2000, Jakarta, 2001.

[9] Gunadi, Tax Accounting, Jakarta: Grasindo, 1997, pp. 203-204.

[10] M. Djoko, Tax Accounting, Yogyakarta: Andi, 2006, pp. 155-156

[11] H. John, "Influence commercial income, net income and fiscal correction, compensation losses against taxable income," Research Journal Akuntabilitas, vol. 6, no. 1, pp. 47-59, September 2006.

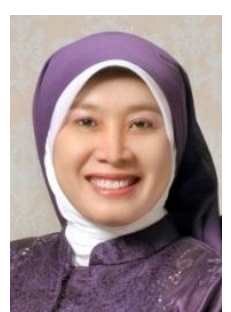

Diana Sari is currently a senior lecturer of Widyatama University for accounting program, magister accounting program (the master degree), and professional accounting education. She is a member of The Indonesian Institute of Accountans (IAI). She graduated in Accounting at STIEB and received her Ph.D. of Economic from the Padjadjaran University of Bandung 2012. With wide ranging research, she has published articles in several conference event and journals on her research both nationally and internationally and she had published a few books. Her current research interest focuses on Taxation, and Public Sector Accounting.

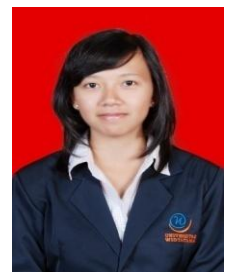

Florentina Anjar Anggraeni is currently an assistant lecturer of Widyatama University for Accounting Program. She graduate in accounting in Widyatama University 